\title{
Analisis Penambatan dan Gerakan Dok Apung Akibat Gaya-Gaya Luar dengan Variasi Konfigurasi Pengikatan pada Perairan Dangkal Terbatas
}

\author{
Fajar Adi Pratama, I Ketut Aria Pria Utama, dan Teguh Putranto \\ Teknik Perkapalan, Fakultas Teknologi Kelautan, Institut Teknologi Sepuluh Nopember (ITS) \\ Jl. Arief Rahman Hakim, Surabaya 60111 Indonesia \\ e-mail:kutama@na.its.ac.id
}

\begin{abstract}
Abstrak-Perilaku struktur apung tertambat dipengaruhi oleh beberapa hal diantaranya muatan, angin, arus, gelombang dan faktor eksternal maupun internal lainnya. Dalam penelitian ini, metode difraksi 3 dimensi dengan program komputer digunakan untuk perhitungan respons gerakan dan ketahanan sistem penambatan struktur apung di gelombang irreguler yang ditinjau dari perairan Selat Madura. Bentuk struktur apung yang dianalisis adalah dok apung dengan bentuk lambung ponton. Dok apung tersebut kemudian divariasikan menjadi 3 kondisi muatan yaitu muatan kosong, muatan kapal dan muatan balas penuh. Variasi juga dilakukan pada konfigurasi penambatan I dan II. Kemudian variasi dilihat untuk perubahan gerakan struktur dan tegangan pada sistem penambatan dok apung. Sudut datangnya gaya eksternal juga divariasikan dalam interval 450, yaitu 00, 450, 900, 1350, 1800, $-450,-900$ dan -1350 . Setelah analisis numerik dilakukan dapat diketahui perubahan muatan menyebabkan perubahan gerakan dan tegangan tali dok apung. Gerakan dok apung berupa perpindahan translasi maupun rotasi dan akselerasi secara vertikal telah memenuhi ketentuan ISO 2631 dan DNV-0030/ND. Tegangan yang dihasilkan pada variasi juga sudah memenuhi kriteria dari API RP2SK2nd edition 1999 untuk kondisi ULS.
\end{abstract}

Kata Kunci- dok apung, konfigurasi, gerakan, tegangan.

\section{PENDAHULUAN}

$\mathrm{R}^{\mathrm{m}}$ EPARASI kapal adalah tindakan untuk memulihkan kondisi mutu awal dari sebuah kapal dengan usaha penggantian/perbaikan dari bagian konstruksi atau permesinan yang dinilai akan membahayakan dari segi keselamatan pelayaran jika dioperasikan lebih lanjut [1]. Untuk melakukan proses reparasi dibutuhkan lahan yang relatif luas seiring dengan kapasitas kapal yang akan direparasi. Seperti yang diketahui bahwa harga lahan/tanah secara cepat naik seiring berjalannya waktu. Untuk itu, diperlukan suatu solusi untuk meredam laju pembengkakan harga tanah dengan melihat kembali identitas negara Indonesia.

Dalam hal tersebut, maka dibutuhkan suatu bangunan terapung yang dapat difungsikan sebagai tempat reparasi kapal atau yang biasa disebut dengan dok apung. Bangunan terapung cenderung mengalami kelelahan karena beban lingkungan yang bekerja didominasi oleh gelombang yang bersifat siklis, sehingga tegangan adalah penyebab utama kerusakan pada bangunan lepas pantai, di mana struktur merespon secara dinamis gelombang acak serta beban arus dan angin.

Untuk menjaga gerakan Dok Apung tersebut supaya tetap pada tempat ia beroperasi maka diperlukan adanya suatu sistem tambat. Salah satu sistem tambat yang banyak digunakan untuk dok apung adalah sistem tambat spread dengan instalasi katener. spread digunakan untuk menjaga gerakan dok apung dari kondisi lingkungan yang ekstrim.

Analisis penambatan dan gerakan merupakan suatu cara yang dapat dilakukan untuk memperkirakan risiko terjadinya kerusakan yang diakibatkan oleh beban berulang, usia dari suatu bangunan dalam menghadapi beban tersebut dan batas aman dalam olah gerak kapal sebagai acuan dalam melakukan desain penambatan dok apung [2]. Selain faktor keamanan, kriteria yang akan ditetapkan dalam desain pemodelan sistem tambat dok apung juga menyangkut faktor kenyamanan. Faktor kenyamanan dapat diketahui melalui motion sickness incidence yang berhubungan dengan percepatan struktur secara vertikal dan lateral [3].

Pembahasan ini melaporkan hasil analisis perhitungan numerik tegangan pada sistem tambat dan gerakan dok apung akibat beban-beban eksternal (beban gelombang, beban angin dan beban arus) pada kondisi perairan dangkal dan dibatasi oleh dermaga pada salah satu sisi. Kemajuan pada bidang ICT juga telah memberikan kontribusi dimana pada saat ini telah terdapat beberapa program yang dapat digunakan untuk menganalisis gerakan maupun tegangan pada sistem tambat bangunan terapung.

\section{METODOLOGI PENELITIAN}

Pada bagian ini, akan diterangkan mengenai metode yang penulis lakukan dari awal sampai terselesaikannya penelitian. Untuk memudahkan pembaca, penulis akan memberikan diagram alir seperti pada Gambar 1.

Seperti yang dihadirkan dalam Gambar 1, langkah pertama yang dilakukan adalah mencari dan memanfaatkan literatur baik dari buku maupun pengalaman penelitian yang telah dipublikasikan sebelumnya. Seperti untuk pemodelan dan perancangan awal dok apung yang memiliki dimensi utama 
$155,4 \mathrm{~m} \times 31 \mathrm{~m} \times 12,7 \mathrm{~m}(\mathrm{~L} \times \mathrm{B} \times \mathrm{H})$ ini mengacu pada penelitian terdahulu. Dari acuan tersebut, perancangan dok apung dibuat dengan melakukan validasi terhadap ukuran sebenarnya.

Pada Gambar 2 merupakan model dok apung yang akan dilakukan validasi. Setelah desain dok apung dimodelkan, dilakukan perhitungan hidrostatis untuk mendapatkan displasemen serta ukuran-ukuran lain dari dok apung. Ukuranukuran tersebut kemudian digunakan untuk kepentingan validasi. Perlu diketahui bahwa pemodelan dok apung pada penelitian ini dilakukan untuk 3 (tiga) macam kondisi muatan. Yang pertama, pemodelan untuk dok apung kondisi muatan kosong yang memiliki sarat air $(\mathrm{T})=1,25 \mathrm{~m}$. Kemudian yang kedua adalah untuk dok apung kondisi memuat kapal yang memiliki sarat air $(\mathrm{T})=2,3 \mathrm{~m}$. Dan yang ketiga adalah dok apungkondisi muatan balas penuh yang memiliki sarat air (T) $=9 \mathrm{~m}$. Karena data utama yang digunakan pada penelitian merupakan data dok apung kondisi muatan kosong maka yang dilakukan validasi adalah hasil perhitungan hidrostatis pada dok apung muatan kosong juga. Berikut hasil validasi tersebut.

Hasil validasi model menunjukkan bahwa model yang dirancang tersebut sudah layak untuk digunakan dalam analisis karakteristik gerakannya. Hal ini karena selisih hasil perancangan dan data acuan sudah memenuhi kriteria.

Setelah hasil model dok apung terbukti valid, langkah selanjutnya adalah membuat model dermaga pada salah satu sisi dengan jarak tertentu. Jarak penempatan antara dermaga dengan dok apung sejauh $5 \mathrm{~m}$ [2]. Pemodelan dermaga langsung pada perangkat lunak yang akan digunakan untuk proses analisis. Sebelum itu, model hasil dok apung terlebih dahulu harus diimpor kedalam ansys aqwa dengan menyesuaikan format dan geomeri.

Terdapat beberapa cara yang dapat dilakukan untuk memodelkan dermaga karena bentuknya yang sangat sederhana. Perangkat lunak ansys aqwa dipilih untuk memodelkan struktur dermaga.

Ansys aqwa merupakan suatu perangkat lunak dengan kemampuan menganalisis model leboh dari satu (multi body), dimana dapat dipilih benda mana yang akan dianalisis dan benda yang mengalami interaksi. Untuk mengetahui interaksi dermaga terhadap gerakan dok apung maka akan dibuat perbandingan nilai RAO gerakan dari dok apung antara ada dan tiadanya dermaga.

Terdapat beberapa parameter kondisi yang dapat mengakibatkan terjadinya interaksi atau efek antara kapal dengan dermaga (bank effects), diantaranya: karakteristik geometri kapal dan karakteristik dermaga, rasio antara kedalaman dengan sarat dan jarak lateral antara kapal dengan dermaga [4]. Sebenarnya terdapat lebih banyak lagi parameter namun parameter lainnya lebih pada interaksi akibat manuver, sedangkan untuk dok apung lebih pada gerakan sea keeping.

Perairan dangkal memiliki karakteristik yang berbeda dibandingkan dengan karakteristik perairan dalam. Perbedaan tersebut ada pada ketidakteraturan perubahan partikel pada perairan dangkal [5]. Efek dari perairan mempengaruhi nilai dari parameter berikut:

Elevasi gelombang:

$\zeta(3)=\zeta_{A \varsigma Q S}(k x-\omega t)$

Panjang gelombang:

$\lambda=\frac{2 \pi j}{w^{2}} \tanh k h$

Kecepatan gelombang:

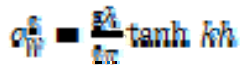

Pada Penelitian ini, dalam analisisnya akan digunakan gelombang irreguler karena cocok digunakan pada perairan pantai [6]. spektrum gelombang Jonswap yang merupakan proyek yang dilakukan pada perairan laut utara. Formulasi spektrum Jonswap merupakan modifikasi dari spektrum Pierson-Moskowitz. Spektrum Jonswap mendeskripsikan angin yang membangkitkan gelombang dengan kondisi sea state yang ekstrim. Seperti halnya dalam penelitian ini, karena berada pada perairan pantai selat madura spektrum Jonswap dapat digunakan dengan nilai gamma tertentu. Untuk perairan dengan ketinggian yang rendah maka dapat digunakan nilai gamma yang rendah [7].

Spektrum Jonswap dapat diaplikasikan pada perairan pantai berdasarj $=$ kan persamaan berikut.

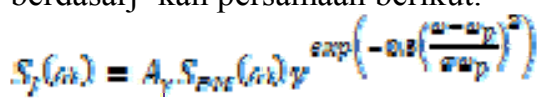

Dimana, A_ $\gamma$ adalah faktor normalisasi, S_PM $(\omega)$ adalah spektrum Pierson-Moskowitzs, $\gamma$ adalah faktor puncak, dan $\sigma$ adalah parameter lebar spektral.

Karakteristik dan respon gerakan struktur dok apung pada penelitian ini dianalisis dalam kondisi tertambat dengan sistem katener. Kondisi tertambat akan divariasikan menjadi dua konfigurasi sesuai kondisi lingkungan perairan, secara menyilang dan menjalar lurus. Kalimat tersebut dapat diperjelas pada Gambar 4 berikut:

Pengikatan dok apung pada dermaga seutuhnya menggunakan wire rope dan pengikatan pada dasar perairan (jangkar) menggunakan rantai secara utuh. Secara kesuluruhan terdapat 6 titik pengikatan oleh rantai dan 2 titik pengikatan oleh wire rope.

Konfigurasi tali tambat yang dipasang pada dok apung didesain memiliki panjang sesuai aturan (Oil Companies International marine Forum (OCIMF). Dimana tali tambat yang digunakan menggunakan 2 tipe komponen yang dibedakan berdasarkan letak penempatan. Komponen tersebut, yaitu rantai dan wire rope dimana keduanya memiliki karakteristik yang optimum pada kondisi tertentu. Rantai dikhusukan untuk pengikatan di dasar perairan sedangkan wire rope untuk pengikatan di atas permukaan perairan, karena secara umum rantai memiliki ketahanan yang baik terhadap abrasi [8].

Analisis dilakukan berdasarkan kondisi lingkungan pengope-rasian dok apung di Selat Madura. Analisis mooring (sistem tambat) yang dilakukan pada Penelitian ini adalah menghitung nilai tension pada setiap tali tambat yang digunakan pada dok apung. Kemudian dari nilai tension masing-masing tali tambat tersebut akan didapatkan nilai tension maksimum yang nantinya akan digunakan untuk pengecekan apakah aman atau tidak. Penegcekan ini 
didasarkan pada nilai faktor keselamatan yang mengacu pada API RP 2SK 2nd edition. Analisis sistem tambat hanya dilakukan untuk pembebanan kondisi all lines intact atau ULS (Ultimate Limit State).

\section{HASIL DAN PEMBAHASAN}

Setelah melalui tahap pemodelan dan pengolahan data, maka akan diperoleh hasil serta pembahasannya. Berikut adalah hasil dan pembahasan dari penelitian yang telah dilakukan:

\section{A. Analisis Perpindahan dan Rotasi Dok Apung,}

Perbedaan respon dok apung saat adanya perubahan muatan ketika kondisi kosong mauupun balas penuh perlu untuk diperiksa. Diharapkan perubahan muatan tidak membuat rentang hasil yang drastis pada dok apung. Muatan dok apung divariasikan menjadi 3 kondisi, yaitu kondisi muatan kosong, kondisi muatan kapal dan kondisi balas penuh. Sudut yang divariasikan untuk gaya eksternal divariasikan setiap 450, yakni $00,450,900,1350,1800,-450,-900$, dan -1350. Pada tiap-tiap variasi tersebut ditinjau menurut konfigurasi pengikatan I dan II.

\section{1) Konfigurasi $I$}

Berikut merupakan hasil analisis perpindahan baik translasi maupun rotasi pada konfigurasi pengikatan I dok apung. Analisis pada Tabel 4, Tabel 5 dan Tabel 6 ditinjau pada tiaptiap arah pembebanan.

Pada analisis kondisi muatan balas penuh terjadi suatu kegagalan dengan durasi 3 jam karena nilai tension saat kisaran waktu 100 sekon mendapatkan nilai yang diluar batas tegangan izin perangkat lunak ansys aqwa. Oleh karena itu nilai pada Tabel 6 merupakan hasil analisis dalam durasi 100 s.

\section{2) Konfigurasi II}

Berikut merupakan hasil analisis perpindahan baik translasi maupun rotasi pada konfigurasi pengikatan II dok apung. Analisis pada Tabel 7, Tabel 8 dan Tabel 9 ditinjau pada tiaptiap arah pembebanan. Max dan min dalam tabel menunjukkan arah gerakan positif dan negatif pada model dok apung.

Sama seperti analisis konfigurasi I, pada analisis kondisi balas untuk konfigurasi II ini juga terjadi suatu kegagalan dalam durasi analisis 3 jam karena nilai tension saat kisaran waktu 100 sekon mendapatkan nilai yang diluar batas tegangan izin ansys aqwa. Oleh karena itu nilai pada Tabel 9 merupakan hasil analisis dalam durasi $100 \mathrm{~s}$.

\section{3) Konfigurasi I Vs Konfigurasi II}

Berdasarkan perbandingan tabel didapati bahwa pada kondisi kosong dan muat penuh dok apung mengalami gerakan lebih tenang saat penambatan secara melintang atau konfigurasi II. Sedangkan gerakan pada kondisi balas nilai maksimal yang didapatkan sama, namun berdasarkan parameter lainnya konfigurasi II mendapatkan nilai yang lebih kecil. Untuk lebih jelasnya ditampilkan dalam bentuk grafik sesuai Gambar 5, Gambar 6 dan Gambar 7.

\section{B. Analisis Akselerasi Gerakan Model Dok Apung}

Analisis percepatan gerakan didapatkan bahwa hasil telah memenuhi kriteria ISO 2631 dengan tingkat nyaman (not uncomfortable). Hasil tersebut seperti yang ditunjukkan pada Tabel 10 yakni, kriteria percepatan $<0,315 \mathrm{~m} / \mathrm{s} 2$.

\section{Analisis Tension tali penambatan}

Analisis tension tali tambat untuk dok apung dilakukan pada kondisi ULS didasarkan pada kriteria yang diijinkan oleh API RP 2SK 2nd edition. Faktor keamanan yang diberikan adalah sebagai berikut:

- Untuk wire rope,

\begin{tabular}{|c|c|}
\hline Safety factor & 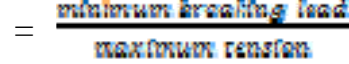 \\
\hline 1,67 & $=\frac{2110000}{\text { maลเพWW fengtom: }}$ \\
\hline Maximum tension & $=1263473.05 \mathrm{~N}$ \\
\hline
\end{tabular}

- Untuk rantai,

Safety factor

1,67

Maximum tension

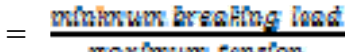

$$
\begin{aligned}
& \text { caxtownon tenstan } \\
& =1411000 \\
& \text { maxtrww tension } \\
& =844910.18 \mathrm{~N}
\end{aligned}
$$

Berdasarkan kriteria yang diberikan, hasil secara keseluruhan ditunjukkan pada Tabel 11 dan Tabel 12.

Berdasarkan hasil analisis muatan kosong dan muatan kapal yang didapatkan bahwa untuk komponen rantai masih berada dalam batas aman sesuai kriteria API, namun untuk wire rope dibutuhkan spesifikasi jenis yang lebih baik lagi.

Berdasarkan hasil analisis yang telah dilakukan seperti yang ditunjukkan pada Tabel 12, tegangan maksimal yang dihasilkan pada seluruh material pengikatan tidak memenuhi kriteria untuk pengujian $3 \mathrm{jam}$. Namun hal tersebut tidak dapat dijadikan sebagai dasar dalam menentukan kriteria keamana untuk sistem tambat dok apung kondisi muatan balas penuh karena pengujian hanya dilakukan dalam durasi 100 sekon.

\section{Analisis Dermaga sebagai Break Waters}

Pada suatu kasus tertentu, dermaga memiliki dimensi panjang yang cukup besar sehingga menyebabkan redaman 


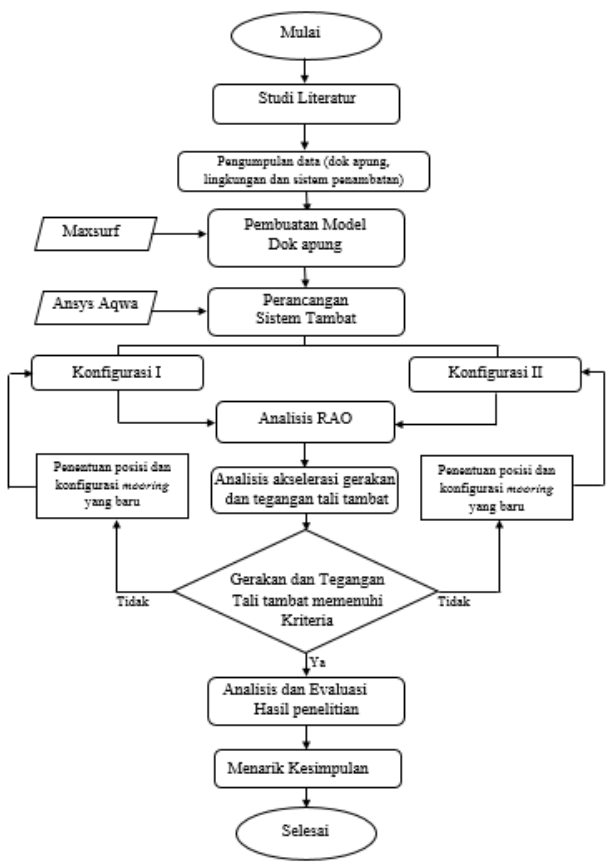

Gambar 1. Diagram alir metode penelitian

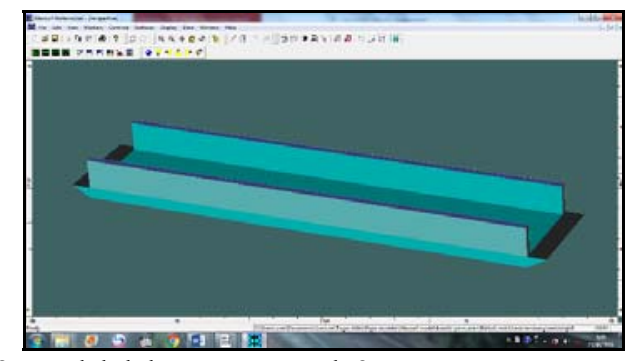

Gambar 2. Model dok apung tampak 3D

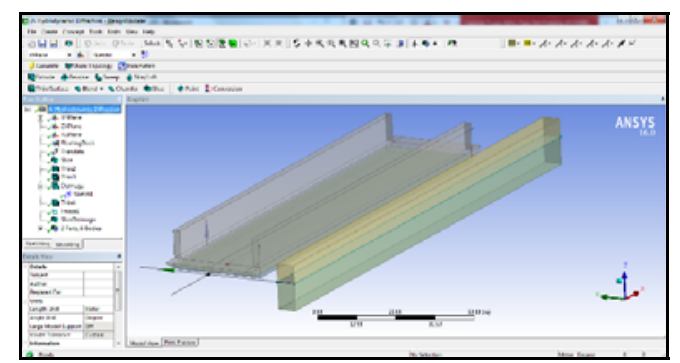

Gambar 3. Pemodelan dok apung dan dermaga pada ansys aqwa

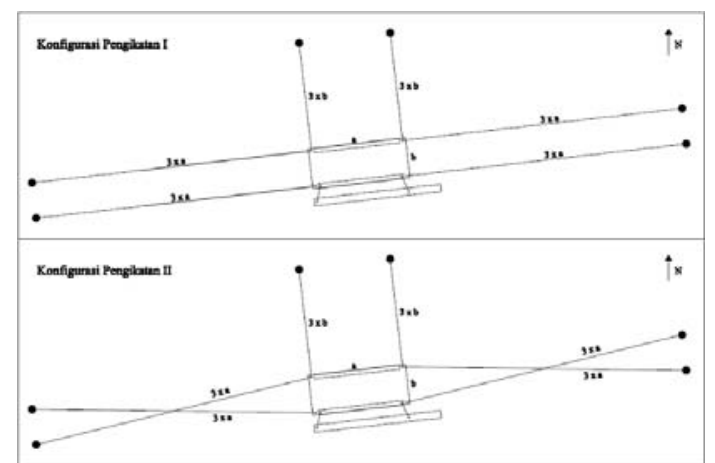

Gambar 4. Variasi Konfigurasi sistem penambatan pada dok apung

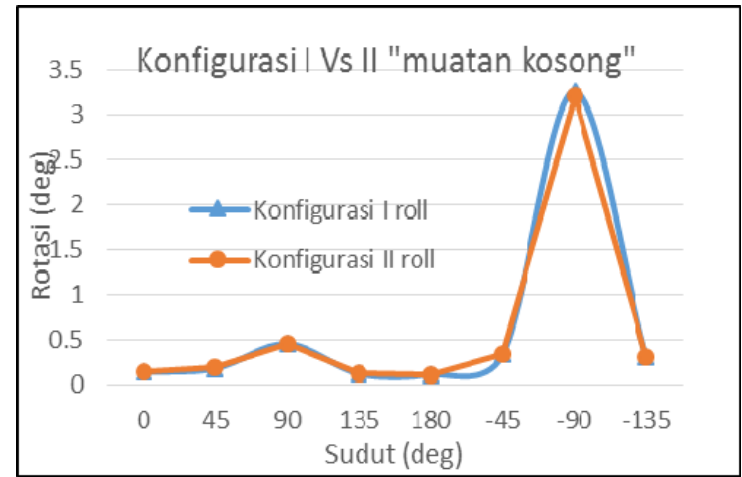

Gambar 5. Grafik perbandingan rolling konfigurasi I dan II saat kondisi muatan kosong

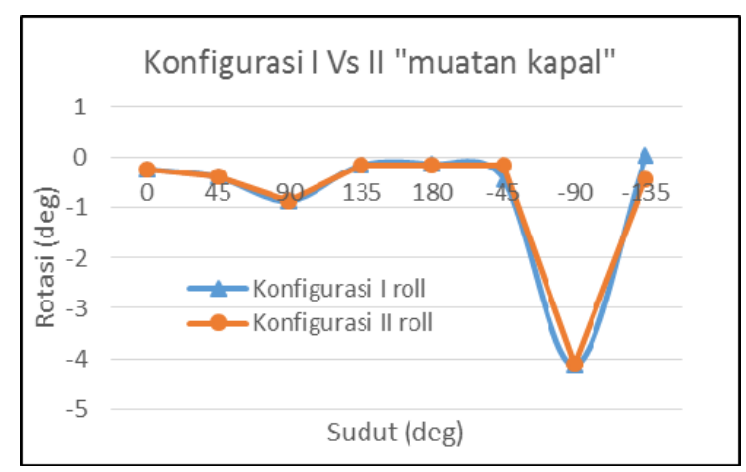

Gambar 6. Grafik perbandingan rolling konfigurasi I dan II saat kondisi muatan kapal

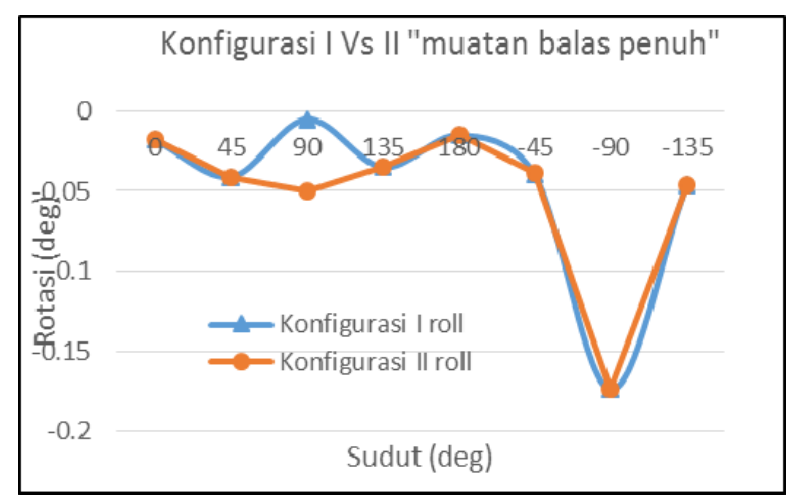

Gambar 7. Grafik perbandingan rolling Konfigurasi I dan II saat muatan balas penuh

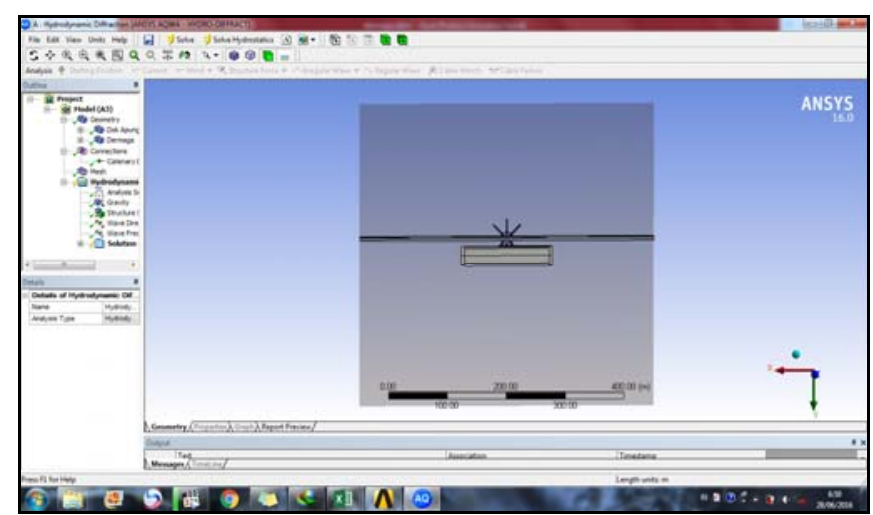

Gambar 8. Dermaga sebagai break waters 


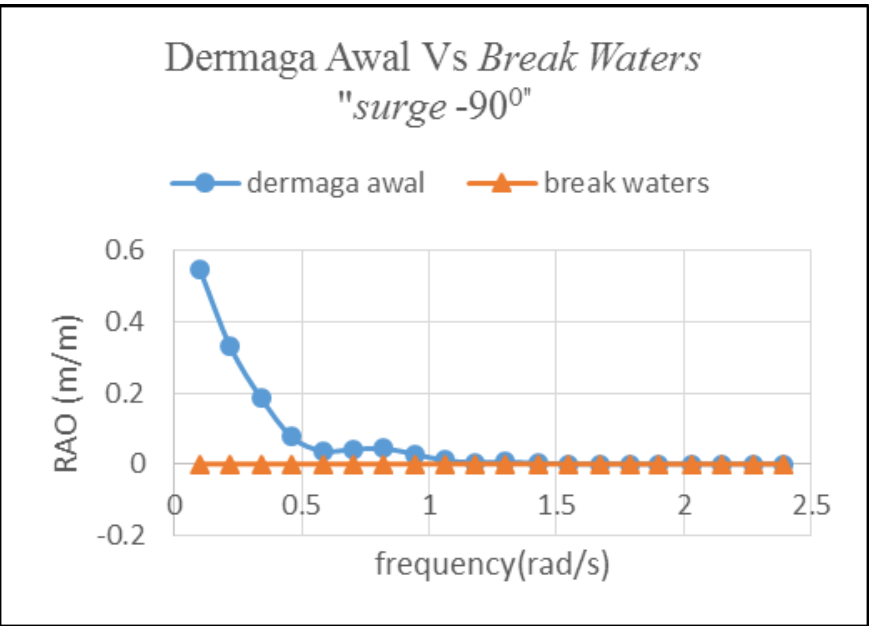

Gambar 9. Perbandingan surging RAO dermaga awal dengan dermaga sebagai break waters

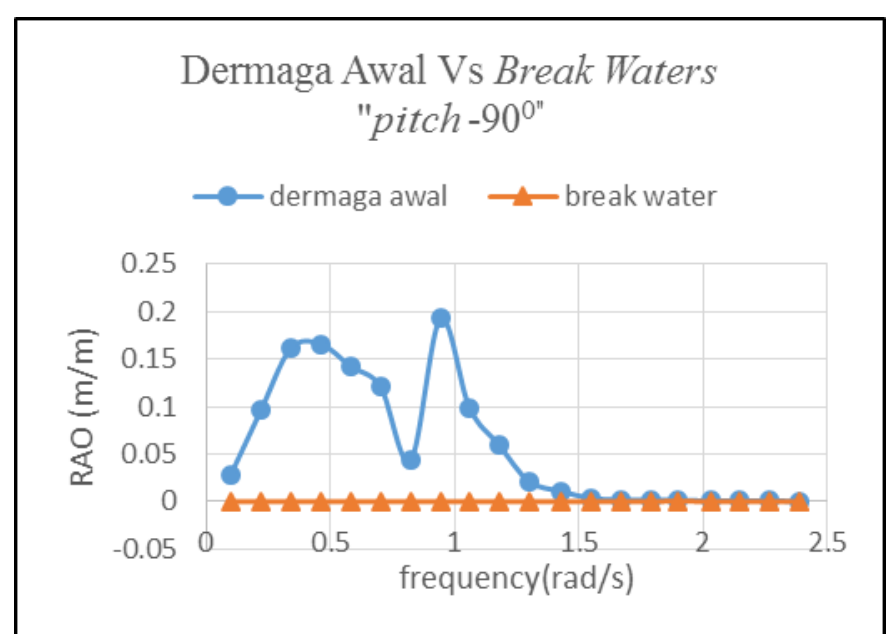

Gambar 10. Perbandingan pitching RAO dermaga awal dengan dermaga sebagai break waters.

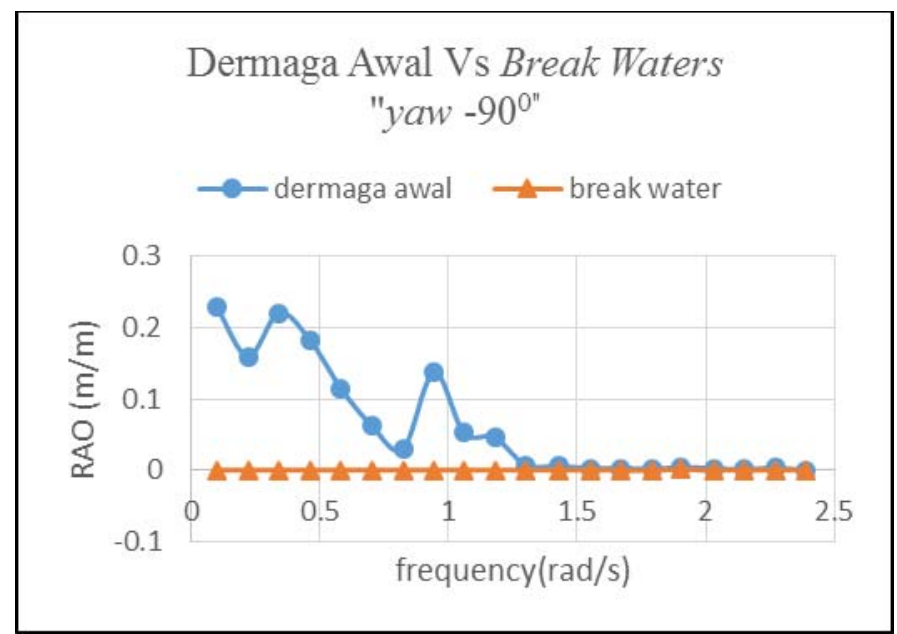

Gambar 11. Perbandingan yawing RAO dermaga awal dengan dermaga sebagai break waters
Tabel 1. Validasi model

\begin{tabular}{|l|l|c|c|c|c|c|}
\hline \multirow{2}{*}{ Parameter } & \multirow{2}{*}{ Satuan } & \multirow{2}{*}{ Data } & \multirow{2}{*}{$\begin{array}{c}\text { Hasil } \\
\text { Pemodelan }\end{array}$} & \multirow{2}{*}{$\begin{array}{c}\text { Selisih } \\
(\%)\end{array}$} & \multicolumn{2}{|c|}{ Kriteria } \\
\cline { 6 - 8 } & & & & & ABS & Ket. \\
\hline Displasemen & $\mathrm{kg}$ & 5672000 & 5746959 & $-1,304$ & $<2 \%$ & memenuhi \\
\hline Sarat & $\mathrm{m}$ & 1,25 & 1,25 & 0 & $<1 \%$ & memenuhi \\
\hline Panjang & $\mathrm{m}$ & 155,4 & 155,4 & 0 & $<1 \%$ & memenuhi \\
\hline Lebar & $\mathrm{m}$ & 31 & 31 & 0 & $<1 \%$ & memenuhi \\
\hline Tinggi & $\mathrm{m}$ & 12.7 & 12,7 & 0 & $<1 \%$ & memenuhi \\
\hline
\end{tabular}

Tabel 3. Data Lingkungan Operasi.

\begin{tabular}{|c|c|c|c|c|c|c|c|}
\hline \multirow{2}{*}{$\begin{array}{l}\text { Wilayah } \\
\text { Perairan }\end{array}$} & \multirow{2}{*}{$\begin{array}{c}\text { Arah } \\
\text { Angin }\end{array}$} & \multirow{2}{*}{$\begin{array}{c}\text { Kec. } \\
\text { Angin } \\
\text { Max } \\
\text { (knot) }\end{array}$} & \multirow{2}{*}{$\begin{array}{c}\begin{array}{c}\text { Tinggi } \\
\text { gelombang }\end{array} \\
\begin{array}{c}\text { Max } \\
\text { (meter) }\end{array}\end{array}$} & \multirow{2}{*}{$\begin{array}{l}\text { Tinggi } \\
\text { gelombang } \\
\text { signifikan } \\
\text { (meter) }\end{array}$} & \multirow{2}{*}{$\begin{array}{c}\begin{array}{c}\text { Kecepatan } \\
\text { Arus }\end{array} \\
\begin{array}{c}\text { Max } \\
\text { (meter/sekon) }\end{array}\end{array}$} & \multicolumn{2}{|c|}{ Pasang Surut } \\
\hline & & & & & & $\begin{array}{c}\text { Max } \\
\text { (meter) }\end{array}$ & $\begin{array}{c}\text { Min } \\
\text { (meter) }\end{array}$ \\
\hline $\begin{array}{c}\text { Selat } \\
\text { Madura }\end{array}$ & $\begin{array}{c}\text { Timur - } \\
\text { Tenggara }\end{array}$ & $2-20$ & $0,5-1,3$ & $0,3-0,8$ & $0,1-1$ & 0,07 & $-0,09$ \\
\hline
\end{tabular}

Data pada Tabel 3 dibutuhkan sebagai parameter masukan dalam analisis numeris gerakan dan tension sistem tambat model pada perangkat lunak.

Tabel 4. Hasil analisis konfigurasi I saat muatan kosong

\begin{tabular}{|c|c|c|c|c|c|c|c|c|c|c|c|c|}
\hline \multirow{3}{*}{$\begin{array}{l}\text { SUDUT } \\
\text { (deg) }\end{array}$} & \multicolumn{6}{|c|}{ Distance $(\mathrm{m})$} & \multicolumn{6}{|c|}{ Rotation (deg) } \\
\hline & \multicolumn{2}{|c|}{ Surge } & \multicolumn{2}{|c|}{ Sway } & \multicolumn{2}{|c|}{ Heave } & \multicolumn{2}{|c|}{ Roll } & \multicolumn{2}{|c|}{ Pitch } & \multicolumn{2}{|c|}{ Yaw } \\
\hline & $\max$ & $\min$ & $\max$ & $\min$ & $\max$ & $\min$ & $\max$ & $\min$ & $\max$ & $\min$ & $\max$ & $\min$ \\
\hline 0 & 0.043 & -0.044 & 0.031 & -0.028 & 0.032 & -0.032 & 0.132 & -0.117 & \begin{tabular}{l|l}
0.092 \\
\end{tabular} & -0.1 & 0.046 & -0.048 \\
\hline 45 & 0.032 & -0.031 & 0.03 & -0.031 & 0.026 & -0.029 & 0.175 & -0.196 & 0.104 & -0.094 & 0.084 & -0.077 \\
\hline 90 & 0.016 & -0.015 & 0.125 & -0.137 & 0.076 & -0.085 & 0.454 & -0.514 & 0.053 & -0.051 & 0.035 & -0.035 \\
\hline 135 & 0.03 & -0.033 & 0.02 & -0.02 & 0.027 & -0.028 & 0.116 & -0.111 & 0.095 & -0.093 & 0.07 & -0.054 \\
\hline 180 & 0.041 & -0.044 & 0.026 & -0.025 & 0.031 & -0.033 & 0.109 & -0.099 & 0.093 & -0.093 & 0.056 & -0.051 \\
\hline-45 & 0.065 & -0.061 & 0.086 & -0.083 & 0.057 & -0.058 & 0.331 & -0.319 & 0.19 & -0.201 & 0.184 & -0.201 \\
\hline-90 & 0.016 & -0.021 & 0.76 & -0.766 & 0.308 & -0.275 & 3.257 & -3.16 & 0.068 & -0.063 & 0.031 & -0.035 \\
\hline-135 & 0.057 & -0.059 & 0.082 & -0.075 & 0.048 & -0.044 & 0.305 & -0.31 & 0.237 & -0.215 & 0.201 & -0.193 \\
\hline
\end{tabular}

Tabel 5. Hasil analisis konfigurasi I saat muatan kapal.

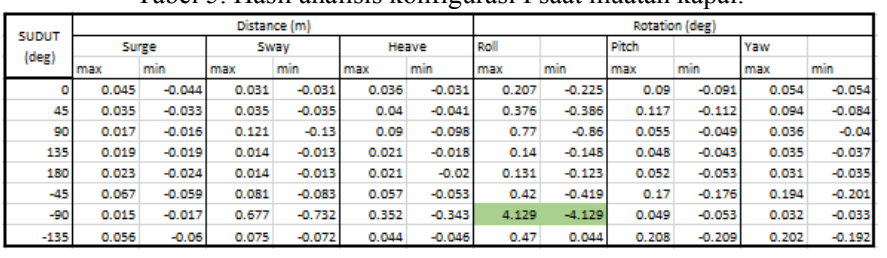

Tabel 6. Hasil analisis konfigurasi I saat muatan balas penuh.

\begin{tabular}{|c|c|c|c|c|c|c|c|c|c|c|c|c|}
\hline \multirow{3}{*}{$\begin{array}{l}\text { SUDUT } \\
\text { (deg) }\end{array}$} & \multicolumn{6}{|c|}{ Distance $[\mathrm{m}]$} & \multicolumn{6}{|c|}{ Rotation (deg) } \\
\hline & \multicolumn{2}{|c|}{ Surge } & \multicolumn{2}{|c|}{ Sway } & \multicolumn{2}{|c|}{ Heave } & \multirow{2}{*}{$\begin{array}{l}\text { Roll } \\
\max \end{array}$} & \multirow[b]{2}{*}{$\min$} & Pitch & \multirow[b]{2}{*}{$\min$} & \multirow{2}{*}{\begin{tabular}{|l|} 
Yaw \\
max
\end{tabular}} & \multirow[b]{2}{*}{$\min$} \\
\hline & $\max$ & $\min$ & $\mid \max$ & $\min$ & $\mid \max$ & $\min$ & & & $\max$ & & & \\
\hline 0 & 0.027 & -0.031 & 0.031 & -0.031 & 0.015 & $\begin{array}{l}-0.017 \\
\end{array}$ & 0.016 & -0.018 & 0.023 & -0.025 & 0.021 & -0.022 \\
\hline 45 & 0.013 & -0.016 & 0.054 & -0.059 & 0.024 & -0.024 & 0.045 & -0.041 & 0.022 & -0.019 & 0.04 & -0.019 \\
\hline 90 & 0.005 & -0.0 & 0.101 & & 0.04 & & 0.008 & -0.005 & 0.016 & -0.014 & 0.048 & -0.014 \\
\hline 135 & 0.014 & -0.011 & 0.043 & -0.047 & 0.02 & -0.021 & 0.038 & -0.035 & 0.02 & -0.022 & 0.045 & -0.048 \\
\hline 180 & 0.028 & -0.028 & 0.023 & -0.025 & 0.013 & -0.015 & 0.02 & -0.015 & 0.025 & -0.023 & 0.023 & -0.024 \\
\hline-45 & 0.013 & -0.013 & 0.036 & -0.036 & 0.013 & -0.013 & 0.04 & -0.04 & 0.069 & -0.058 & 0.042 & -0.039 \\
\hline-90 & 0.007 & -0.008 & 0.148 & -0.118 & 0.062 & -0.056 & 0.167 & -0.177 & 0.007 & -0.007 & 0.01 & -0.011 \\
\hline-135 & 0.012 & -0.012 & 0.049 & -0.05 & 0.012 & -0.011 & 0.052 & -0.046 & 0.047 & -0.042 & 0.071 & -0.072 \\
\hline
\end{tabular}

Tabel 7. Hasil analisis konfigurasi II saat muatan kosong.

\begin{tabular}{|c|c|c|c|c|c|c|c|c|c|c|c|c|}
\hline \multirow{3}{*}{$\begin{array}{c}\text { SUDUT } \\
\text { (deg) }\end{array}$} & \multicolumn{6}{|c|}{ Distance $(\mathrm{m})$} & \multicolumn{6}{|c|}{ Rotation (deg) } \\
\hline & \multicolumn{2}{|c|}{ Surge } & \multicolumn{2}{|c|}{ Sway } & \multicolumn{2}{|c|}{ Heave } & \multicolumn{2}{|c|}{ Roll } & \multicolumn{2}{|c|}{ Pitch } & \multicolumn{2}{|c|}{ Yaw } \\
\hline & $\max$ & $\min$ & $\max$ & $\min$ & $\max$ & $\min$ & $\max$ & $\min$ & $\max$ & $\min$ & $\max$ & $\min$ \\
\hline 0 & 0.043 & -0.044 & 0.031 & -0.028 & 0.032 & -0.032 & 0.132 & -0.117 & 0.092 & -0.1 & 0.046 & -0.048 \\
\hline 45 & 0.032 & -0.035 & 0.032 & -0.03 & 0.028 & -0.029 & 0.187 & -0.183 & 0.096 & -0.103 & 0.065 & -0.068 \\
\hline 90 & 0.017 & -0.016 & 124 & -0.136 & 0.076 & -0.085 & 456 & -0.515 & 0.053 & -0.049 & 0.035 & -0.034 \\
\hline 135 & 0.03 & -0.033 & 0.02 & -0.02 & 0.027 & -0.028 & 0.115 & -0.112 & 0.096 & -0.091 & 0.07 & -0.064 \\
\hline 180 & 0.041 & -0.045 & 0.026 & -0.025 & 0.031 & -0.033 & 0.109 & -0.099 & 0.094 & -0.092 & 0.056 & -0.05 \\
\hline-45 & 0.065 & -0.06 & 0.086 & -0.062 & 0.059 & -0.057 & 0.331 & -0.308 & 0.189 & -0.201 & 0.185 & -0.199 \\
\hline-90 & 0.019 & -0.021 & 0.755 & -0.773 & 0.311 & -0.277 & 3.204 & -3.185 & 0.071 & -0.075 & 0.032 & -0.032 \\
\hline -135 & 0.055 & -0.06 & 0.082 & -0.075 & 0.048 & -0.044 & 0.307 & -0.297 & 0.237 & -0.217 & 0.201 & -0.191 \\
\hline
\end{tabular}

Tabel 8. Hasil analisis konfigurasi II saat muatan kapal.

\begin{tabular}{|c|c|c|c|c|c|c|c|c|c|c|c|c|}
\hline \multirow{3}{*}{$\begin{array}{c}\text { SUDUT } \\
\text { (deg) }\end{array}$} & \multicolumn{6}{|c|}{ Distance $(\mathrm{m})$} & \multicolumn{6}{|c|}{ Rotation (deg) } \\
\hline & \multicolumn{2}{|c|}{ Surge } & \multicolumn{2}{|c|}{ Sway } & \multicolumn{2}{|c|}{ Heave } & \multicolumn{2}{|c|}{ Roll } & \multicolumn{2}{|c|}{ Pitch } & \multicolumn{2}{|c|}{ Yaw } \\
\hline & $\max$ & $\min$ & $\max$ & $\min$ & $\max$ & $\min$ & $\max$ & $\min$ & $\max$ & $\min$ & $\max$ & $\min$ \\
\hline 0 & 0.045 & -0.044 & 0.031 & -0.031 & 0.036 & -0.031 & 0.207 & -0.224 & 0.09 & -0.091 & 0.054 & -0.054 \\
\hline 45 & 0.035 & -0.033 & 0.035 & -0.035 & 0.039 & -0.042 & 0.373 & -0.387 & 0.117 & -0.112 & 0.094 & -0.083 \\
\hline 90 & 0.017 & -0.016 & 0.122 & -0.13 & 0.069 & -0.098 & 0.775 & -0.858 & 0.055 & -0.049 & 0.036 & -0.04 \\
\hline 135 & 0.032 & -0.036 & 0.022 & -0.024 & 0.025 & -0.027 & 0.166 & -0.153 & 0.08 & -0.085 & 0.074 & -0.069 \\
\hline 180 & 0.044 & -0.046 & 0.028 & -0.027 & 0.03 & -0.031 & 0.156 & -0.157 & 0.08 & -0.08 & 0.058 & -0.056 \\
\hline-45 & 0.028 & -0.028 & 0.031 & -0.03 & 0.026 & -0.028 & 0.206 & -0.154 & 0.067 & -0.082 & 0.065 & -0.09 \\
\hline-90 & 0.015 & -0.016 & 0.679 & -0.725 & 0.348 & -0.329 & 3.735 & -4.12 & 0.045 & -0.053 & 0.032 & -0.032 \\
\hline-135 & 0.056 & -0.059 & 0.075 & -0.072 & 0.044 & -0.046 & 0.463 & -0.437 & 0.207 & -0.207 & 0.202 & -0.195 \\
\hline
\end{tabular}


Tabel 9. Hasil analisis konfigurasi II saat muatan balas penuh.

\begin{tabular}{|c|c|c|c|c|c|c|c|c|c|c|c|c|}
\hline \multirow{3}{*}{$\begin{array}{c}\text { SUDUT } \\
\text { (deg) }\end{array}$} & \multicolumn{6}{|c|}{ Distance $(m)$} & \multicolumn{6}{|c|}{ Rotation (deg) } \\
\hline & \multicolumn{2}{|c|}{ Surge } & \multicolumn{2}{|c|}{ Sway } & \multicolumn{2}{|c|}{ Heave } & \multicolumn{2}{|c|}{ Roll } & \multicolumn{2}{|c|}{ Pitch } & \multicolumn{2}{|c|}{ Yaw } \\
\hline & $\max$ & $\min$ & $\max$ & $\min$ & $\max$ & $\min$ & $\max$ & $\min$ & $\max$ & $\min$ & $\max$ & $\min$ \\
\hline & 0.027 & -0.031 & 0.032 & -0.031 & 0.015 & -0.017 & 0.016 & -0.018 & 0.023 & -0.025 & 0.021 & -0.022 \\
\hline 45 & 0.013 & -0.016 & 0.054 & -0.058 & 0.024 & -0.024 & 0.044 & -0.041 & 0.022 & -0.019 & 0.046 & -0.054 \\
\hline 90 & 0.005 & -0.007 & 0.104 & -0.101 & 0.04 & -0.042 & 0.046 & -0.05 & 0.006 & -0.005 & 0.017 & -0.015 \\
\hline 135 & 0.013 & -0.01 & 0.043 & -0.047 & 0.02 & -0.021 & 0.036 & -0.035 & 0.02 & -0.022 & 0.049 & -0.048 \\
\hline 180 & 0.029 & -0.028 & 0.023 & -0.025 & 0.013 & -0.015 & 0.02 & -0.015 & 0.025 & -0.023 & 0.023 & -0.024 \\
\hline-45 & 0.013 & -0.013 & 0.036 & -0.038 & 0.013 & -0.013 & 0.042 & -0.039 & 0.044 & -0.04 & 0.068 & -0.057 \\
\hline-90 & 0.007 & -0.006 & 0.148 & -0.118 & 0.062 & -0.056 & 0.167 & -0.174 & 0.007 & -0.007 & 0.016 & -0.016 \\
\hline-135 & 0.012 & -0.012 & 0.048 & -0.05 & 0.012 & -0.011 & 0.052 & -0.046 & 0.047 & -0.042 & 0.072 & -0.07 \\
\hline
\end{tabular}

Tabel 10. Nilai akselerasi maksimal

\begin{tabular}{|c|c|c|c|}
\hline \multicolumn{4}{|c|}{ KONFIGURASI I dan KONFIGURASI II } \\
\hline MAKSIMUM AKSELERASI GERAKAN MUATAN KOSONG DAN MUATAN KAPAL \\
\hline Vertikal $\left(\mathrm{m} / \mathrm{s}^{2}\right)$ & ISO 2631 & Kondisi eksternal: & Konfigurasi: \\
\hline 0.308 & not uncomfortable & kosong $\left(-90^{\circ}\right)$ & Konfigurasi I \\
\hline
\end{tabular}

Tabel 11. Besaran nilai maksimal pada konfigurasi I dan II

\begin{tabular}{|l|l|l|c|c|}
\hline Konfigurasi: & Kondisi: & Jenis: & Tegangan (N): & Kriteria (API): \\
\hline \multirow{4}{*}{ Konfigurasi I I } & \multirow{2}{*}{ Muatan Kosong } & Rantai & 794128.1 & $\checkmark$ \\
\cline { 3 - 5 } & & Wire rope & 1415262 & $\mathrm{x}$ \\
\cline { 3 - 5 } & \multirow{2}{*}{ Muatan Kapal } & Rantai & 1603832 & $\checkmark$ \\
\cline { 3 - 5 } & & Wire Rope & 1419582 & $\mathrm{x}$ \\
\hline \multirow{3}{*}{ Konfigurasi II } & \multirow{2}{*}{ Muatan Kosong } & Rantai & 1172172 & $\checkmark$ \\
\cline { 3 - 5 } & & Wire Rope & 1415234 & $\mathrm{x}$ \\
\cline { 3 - 5 } & \multirow{2}{*}{ Muatan Kapal } & Rantai & 1349754 & $\checkmark$ \\
\cline { 3 - 5 } & & Wire Rope & 1419580 & $\mathrm{X}$ \\
\hline
\end{tabular}

Tabel 12. Hasil Tegangan maksimal pada kondisi muatan balas penuh

\begin{tabular}{|l|l|l|c|}
\hline Konfigurasi: & Kondisi: & Jenis: & Tegangan $(\mathrm{N}):$ \\
\hline \multirow{2}{*}{ Konfigurasi I } & $\begin{array}{l}\text { Muatan Balas } \\
\text { Penuh }\end{array}$ & Rantai & 2110068.75 \\
\cline { 3 - 4 } & Wire Rope & 1419841.375 \\
\hline \multirow{2}{*}{ Konfigurasi II } & $\begin{array}{l}\text { Muatan Balas } \\
\text { Penuh }\end{array}$ & Rantai & 2110061.25 \\
\cline { 3 - 4 } & & Wire Rope & 1419854.375 \\
\hline
\end{tabular}

atau hilangnya pengaruh gelombang terhadap salah satu sisi dok apung. Dampak yang diakibatkan menyerupai dampak dari adanya break waters. Pada bahasan kali ini akan dilakukan analisis gerakan dari dok apung dengan kasus dermaga sebagai break waters. Untuk memperjelas kalimat tersebut, ditampilkan gambaran kasus sesuai gambar berikut.

Berdasarkan perbandingan analisis yang telah dilakukan, didapatkan beberapa perbedaan tren yang cukup signifikan antara dermaga awal dengan dermaga sebagai break waters. Hasil perbandingan terhadap perbedaan tersebut akan disajikan dalam bentuk grafik seperti pada gambar berikut.

Keunikan yang didapatkan dalam analisis yang telah dilakukan adalah selisih perbedaan nilai RAO signifikan terjadi hanya pada gerakan manouvering (surge dan yaw) dan gerakan sea keeping (pitch) dengan arah pembebanan gelombang -900. Gaya yang ditimbulkan gelombang dari salah satu sisi dok apung membuat aktifitas gerakan untuk dok apung mengangguk, maju dan mundur serta membelok terhambat hingga mendekati diam.

\section{KESIMPULAN}

Analisis numeris gerakan dan tension model dok apung mendapatkan konfigurasi pengikatan II dengan nilai yang lebih efektif dibandingkan dengan konfigurasi pengikatan I dan gerakan paling dominan terjadi pada arah gaya-gaya eksternal kolinier -900. Berdasarkan hasil analisis, didapatkan kesimpulan sebagai berikut.

Gerakan yang terjadi baik berupa perpindahan, rotasi maupun akselerasi didominasi oleh gaya eksternal kolinier 900. Hal ini terjadi dikarenakan pada arah tersebut area yang terpengaruh oleh gaya eksternal memiliki nilai paling luas sehingga gaya interaksi yang ditimbulkan sangat besar;

Tegangan (tension) paling tinggi dialami rantai oleh dok apung saat gaya eksternal dengan arah kolinier -900 . Tegangan yang paling dominan ini seiring dengan gerakan yang timbul. Ketika gerakan dominan pada saat gaya eksternal kolinier -900 maka tegangan juga akan dominan ketika gaya eksternal di arah -900 .

Konfigurasi pengikatan II lebih efektif dibandingkan konfigurasi pengikatan I, ditinjau dari gerakan maupun tegangan pada tali tambat model dok apung. Seperti fakta dalam hitungan numerik yang telah dilakukan bahwa dalam parameter yang sama konfigurasi tersebut memberikan reduksi yang lebih baik dalam mengendalikan gerakan dok apung.

Penggunaan tali penambatan wire rope dibutuhkan spesifikasi yang lebih tinggi dibanding dengan perencanaa sebelumnya, sebab dalam kondisi ekstrim nilai ketahanan tali tidak sesuai dengan kriteria API;

Terdapat suatu efek (Bank effect) pada dok apung akibat interaksi dengan dermaga, dan juga pada kondisi muatan balas penuh terdapat suatu efek (squat effect) yang menyebabkan gerakan kapal mengalami perubahan. Efek tersebut dapat diketahui melalui perubahan nilai yang terjadi dan visualisasi dari animasi setelah hasil yang didapatkan analisis numerik. Analisis perbandingan variasi kedalaman perairan dan kerapatan dermaga juga dapat mengetahui besaran efek gerakan dan tegangan sistem tambat yang terjadi pada dok apung.

Analisis RAO dok apung terhadap dimensi dan penempatan dermaga yang berbeda (menyerupai break waters) sebagian besar mendapatkan hasil dengan nilai yang relatif sama. Adapun beberapa nilai dengan selisih nilai yang signifikan saat dok apung pada gerakan pitch, yaw dan surge dalam arah pembebanan gelombang -900 .

\section{UCAPAN TERIMA KASIH}

Penulis F.A.P mengucapkan terima kasih kepada kedua orang tua dan saudara-saudara penulis yang senantiasa memberikan motivasi kepada penulis di saat timbulnya rasa keputusasaan serta teman-teman seperjuangan yang turut mendukung hingga terselesaikannya Penelitian ini". "Penulis juga berterima kasih kepada Direktorat Pendidikan Tinggi, Departemen Pendidikan dan Kebudayaan Republik Indonesia yang telah memberikan dukungan finansial melalui Beasiswa BBM/BBP tahun 2013-2016". 


\section{DAFTAR PUSTAKA}

[1] Muhammad, A.N., (2007). Modifikasi ponton pada dok apung (Floating Dock) untuk Menghindari Waktu yang Hilang saat Reparasi. Tugas Akhir. Institut Teknologi Sepuluh Nopember, Surabaya.

[2] Dietrict, G., (2013). Pengaruh Riser terhadap Fatigue Life Tali Tambat Studi Kasus : SPM FPSO Seagood 101. Tugas Akhir. Institut Teknologi Sepuluh Nopember, Surabaya.

[3] Purwanto, R.D., (2012). Perancangan Awal Floating Production Unit (FPU) untuk Lapangan Gas di Selat Madura. Jurnal Sains dan Seni POMITS. Institut Teknologi Sepuluh Nopember, Surabaya.

[4] Vantoree,M., (1999). Review of Practical Methods For Assessing Shallow and Restricted Water Effects. Ghent University, Belgium.

[5] Borkja, J.L.B., (2015). Dynamic Analysis of Floating Dock Structures. Master Thesis. Department of Marine Technology. Norwegian University of Science and Technology. Trondheim, Norway.

[6] Rachman dan Suntoyo., (2012). Prediksi Transportassi Sedimen Akibat Gerakan Gelombang Irreguler. Universitas Hasanuddin, Makasar.

[7] Hasselman, K., Barnett, T.P., Bouws, E., Carlson, H., Cartwright, D.E., Enke, K., Ewing, J.A., Gienapp, H., Hasselmann, D.E., Kruseman, P., Meerburg, A., Muller, P., Olbers, D.J., Richter, K., Sell, W., Walden, H.,., (1973). Measurements of Wind-Wave Growth and Swell Decay during the Joint North Sea Wave Project (JONSWAP). Deutches Hydrographisches Institut. Hamburg.

[8] API RP 2SK 2nd edition. (1996). Recommended Practice for Design and Analysis of Station Keeping Systems for Floating Structures. Washington, DC. 